УДК 347.4

DOI https:// doi.org/10.32837/yuv.v0i1.1636

\author{
А. Колодін, \\ аспірант кафедри цивільного права \\ Національного університету «Одеська юридична академія»

\section{ЩОДО ОСОБЛИВОСТЕЙ ДОГОВОРУ ЧАРТЕРУ (ФРАХТУВАННЯ) ЗА ЦИВІЛЬНИМ ЗАКОНОДАВСТВОМ УКРАЇНИ}

Розвиток бізнесу, розширення міжнародних відносин вимагають від учасників мобільності й оперативності пересування, що не завжди забезпечується регулярним повітряним сполученням. Bсе це зумовило розвиток сегменту чартерних перевезень.

Договором фрахтування судна називають як договір перевезення вантажів, пасажирів, багажу, якщо він укладений з умовою надання для перевезення всього судна або окремих суднових приміщень, так і договір оренди судна з екіпажем або без нього. I в тому, і в іншому випадку сторони можуть називатися однаково - «фрахтувальник (судновласник)» $\mathrm{i}$ «фрахтувальник», предмет договору - переміщення певних обумовлених об'єктів (вантажів, пасажирів, багажу) може бути один і той самий.

Водночас українське право застосовує поняття «договір фрахтування» виключно до перевезення вантажів, пасажирів, багажу. Всі інші форми експлуатації суден є договором оренди судна як транспортного засобу.

Можна звернути увагу на те, що, хоча відносини фрахтування (чартеру) в морському праві досить детально регламентовані на законодавчому рівні, чинне законодавство України в цій сфері не є досконалим.

Теоретичну основу дослідження становлять праці таких науковців, як А.І. Муранов, Д.Л. Давиденко, В.І. Борисова, І.В. Фатєєва, В.Л. Яроцький, Ч.Н. Азімов, М.М. Сібільов, В.І. Борисова, П.Ф. Коваль, Н.О. Алєшугіна, Г.П. Андрєєва, О.В. Столяр- ський, С.С. Бичкова, I.А. Бірюков, Є.О. Харитонов, В.І. Бобрик та ін.

Метою статті $€$ науковий аналіз загальних положень законодавства України $з$ метою визначення особливостей договору фрахтування (чартеру) в цивільному праві України.

Чартер (англ. charter) - у міжнародному торговому мореплавстві та повітряному сполученні різновид договору перевезення вантажу, пасажирів i багажу, синонім договору фрахтування [12].

Чартерні перевезення, що організовуються для перевезення пасажирів, можна розділити на кілька видів: туристичний чартер, VIP-чартер і корпоративний чартер [13].

Договір фрахтування, поміщений у гл. 64 ЦК України «Перевезення», характеризується як угода, котра укладається для переміщення вантажів. За договором чартеру (фрахтування) одна сторона (фрахтівник) зобов'язується надати другій стороні (фрахтувальникові) за плату всю або частину місткості в одному чи кількох транспортних засобах на один або кілька рейсів для перевезення вантажу, пасажирів, багажу, пошти або 3 іншою метою, якщо це не суперечить закону та іншим нормативно-правовим актам.

У ст. 203 Кодексу торговельного мореплавства України (далі - KTM України) дається таке визначення договору фрахтування (чартеру): за договором чартеру (фрахтування) судна на певний час судновласник зобов'язується за обумовлену плату (фрахт) 
надати судно фрахтувальнику для перевезення пасажирів, вантажів і для інших цілей торговельного мореплавства на певний час. Тобто глава 1 розділу VI KTM України регулює виключно тайм-чартер і виділяє тільки два його види, вказавши, що надане фрахтувальнику судно може бути укомплектоване екіпажем (тайм-чартер) або не укомплектований екіпажем (бербоут-чартер).

У юридичній літературі не раз відзначалася схожість цілей укладання договорів фрахтування та перевезення - транспортування вантажу, пасажирів, багажу. Деякі автори вказують на загальну економічну мету договору фрахтування та перевезення - зміну територіального положення об'єкта зобов'язань. Предмет - перевезення - послуги доставки 3 пункту до пункту. Предмет - транспортний засіб (виділення всієї місткості транспортного засобу або ії частини для перевезення вантажу).

Договір фрахтування висвітлений у ЦК України в розділі про перевезення i, отже, повинен розглядатися як угода, що укладається для переміщення вантажів, пасажирів і багажу. Як різновид договору морського перевезення чартер (договір фрахтування судна, його частини або окремих приміщень) передбачений у КТМ України. Норми про чартер є i в Повітряному Кодексі України. Водночас за проектом Закону України «Про внутрішній водний транспорт» від 24 вересня 2019 р. № 1182-2 договір фрахтування укладається для перевезення вантажу, пасажирів і багажу. Сторонами в договорі фрахтування $€$ фрахтувальник і фрахтувальник. Як фрахтувальник виступає власник транспортного засобу (його власник або особа, якій транспортний засіб належить на іншому правовому підставі). Фрахтувальник - юридична або фізична особа, зацікавлена в перевезенні великих партій вантажу або груп пасажирів по маршруту, передбаченому договором фрахтування, який зазвичай не збігається зі встановленими лініями (напрямами) перевезення. Фрахтувальник може бути від- правником або отримувачем вантажу, але може ним і не бути. Наприклад, коли морська судно фрахтується відповідно до договору купівлі-продажу товару його продавцем, а відправлення вантажу на адресу одержувача здійснює виробник товару. У цьому разі фрахтувальник і відправник не збігатимуться в одній особі.

Договір фрахтування (чартер) $€$ двостороннім і оплатним. Його зміст полягає у праві фрахтувальника зарезервувати все обумовлене договором судно, інший транспортний засіб (частину його місткості) для перевезення за плату протягом одного або декількох рейсів, передбачених цим договором вантажів, пасажирів і багажу, а фрахтувальника отримати за надане транспортний засіб (частину його місткості) встановлену угодою сторін плату (іменовану в морському праві фрахтом).

КTM України відносить встановлення порядку укладення договору фрахтування, а також форми зазначеного договору до відання транспортних статутів і кодексів. Відповідно до ст. 136, 138 КТМ України чартер повинен містити найменування сторін, назву судна, вказівку на рід і вид вантажу, розмір фрахту, найменування місця навантаження, а також місця призначення або направлення судна.

У зв'язку із широким застосуванням чартеру у світовій практиці торговельного мореплавства для полегшення його укладення i погодження умов фрахтування судна (його частини або певних суднових приміщень) розроблені проформи (примірні договори) рейсових чартерів. Такі проформи чартерів часто розробляються об'єднаннями судновласників та узгоджуються 3 об'єднаннями власників вантажу, страховиків, брокерів та ін. Проформа чартеру зазвичай має кодове найменування (тайм-чартер, бербоут-чартер, рейсовий чартер, коносамент тощо).

Основним замовником туристичного чартеру є туроператори. Вони безпосередньо або через компанії перевізників фрахтують літак, судно, наземний тран- 
спорт і самі відповідають за його завантаження. Туристичний чартер - послуга пакетна, і квитки на нього зазвичай продають разом із проживанням і харчуванням у готелі, трансфером і медичною страховкою. Маршрути, на яких організовують туристичний чартер, це напрямки, де немає регулярних рейсів або їх недостатньо для перевезення великої потоку туристів [9].

На відміну від туристичного, VIP-чартер і корпоративний чартер виконуються як разові польоти. Маршрут визначається такими факторами: на певному напрямку не виконуються регулярні рейси або потрібно перевезти велику групу людей, i на регулярному рейсі немає в наявності такої кількості вільних місць; замовнику потрібно забезпечити конфіденційність, безпеку своєї поїздки, і він не хоче бути прив'язаний до розкладу регулярних рейсів [14].

Корпоративний чартер необхідний великим компаніям, трупам артистів, музичним гуртам, спортивним командам тощо, тобто всім тим, хто відчуває необхідність у перевезенні великої групи пасажирів за індивідуальним маршрутом [14].

Чартерні перевезення мають ряд переваг як для пасажирів, так і для самих перевізників. Для пасажирів це насамперед ціна на квиток, яка на чартерний рейс значно нижча, ніж на регулярний. Що стосується авіакомпаній, то навесні і влітку попит на авіаперевезення більший, а восени і взимку менший, що пов'язано зі змінами на туристичному ринку.

Особливості регулювання морського перевезення вантажу по коносаменту і на підставі чартеру можна виявити за допомогою порівняльного аналізу, для проведення якого необхідно розглянути питання правового регулювання цих видів морських перевезень.

При перевезенні генеральних, тарно-пакувальних вантажів вантажовласник зазвичай вдається до послуг лінійного судноплавства, за якого підтримується регулярне сполучення на певному напрямку. Окремі українські вчені виділяють такі ознаки лінійного судноплавства: а) регулярність повідомлення і наявність розкладу судів; б) перевезення дорогих генеральних вантажів; в) завантаження судна вантажами багатьох вантажовідправників; г) оплата перевезення за лінійними тарифами; д) здійснення вантажно-розвантажувальних операцій перевізником; е) публічний характер послуг перевізника [4, 8]. Зазначені ознаки багато в чому зумовлюють особливості укладення договорів перевезення.

У разі перевезення вантажу на лінійних судах відносини перевізника і власника вантажу оформляються договором морського перевезення вантажу без надання всього судна, його частини або окремих суднових приміщень, коли перевізник сам формує завантаження судна, вирішує, яким чином і де розмістити вантаж. Взаємні права й обов'язки сторін оформляються коносаментом. Коносамент - це особливий транспортно-комерційний документ, який видає перевізник після прийняття пред'явленого до перевезення вантажу на судно.

Коносамент 3 усіма включеними в нього умовами за своїм обсягом не покриває «своїм безпосереднім змістом усіх прав і обов'язків сторін за договором» $[10$, с. $78-80]$. Він розглядається як доказ наявності договору морського перевезення вантажу.

Основними джерелами регулювання цього договору за українським законодавством $€$ : ратифіковані Україною міжнародні конвенції [4-6], Цивільний кодекс, Кодекс торговельного мореплавства, підзаконні акти органів виконавчої влади в галузі транспорту. Глава 2 «Договір морського перевезення вантажу» розділу V «Морські перевезення» Кодексу торгівельного мореплавства України практично повністю відповідає Гаазько-Вісбійським правилам. Однак частина норм Гамбурзьких правил, які регулюють питання, що не отримали дозволу в Гаазько-Вісбійських правилах, також використана в цій главі. Одні норми використані без будь-яких змін, інші - лише частково. 
Ще однією особливістю глави 2 розділу V KTM України [3] є те, що деякі імперативні норми Гаазько-Вісбійських правил, призначені для застосування під час перевезення вантажу по коносаменту, застосовуються і при перевезеннях по чартеру. Як зазначають А.І. Муранов і Д.Л. Давиденко, україське законодавство, яке регламентує морські перевезення вантажів, досить складне (іноді в зарубіжній юридичній літературі такий тип законодавства називають «гібридним») [11, с. 81-86].

Назва «договір морського перевезення по коносаменту» $€$ умовною. По-перше, така назва не міститься в жодному законодавчому акті Украіни. По-друге, договір морського перевезення вантажу, котрий не є чартером, може бути укладений без використання коносамента, замість якого може бути виданий іншій документ, наприклад, морська накладна, багажна квитанція (ст. 137, 144, 186 КТМ України). По-третє, оформлення сторонами своїх відносин у вигляді чартеру не виключає видачу коносамента. Тому коносамент не можна визнати індивідуальною ознакою договору морського перевезення вантажу без використання всього судна, його частини або певних приміщень.

Згідно зі ст. 133 КТМ України основний зміст цього виду договору морського перевезення вантажу полягає в тому, що перевізник зобов'язується доставити вантаж, який передав або передасть відправник із порту відправлення в порт призначення і видати уповноваженій на одержання вантажу особі, а вантажовідправник - сплатити перевізнику фрахт, провізну плату.

За таким договором відправник не користується правом вимагати, щоб для розміщення вантажу були надані всі вантажні приміщення судна або їх частину.

Кожна зі сторін за цим договором набуває певні права і бере на себе юридичні обов'язки. Перевізник зобов'язується перевезти вантаж і видати його одержувачу, а відправник повинен сплатити за перевезення встановлену плату.
За поширеною в науці морського права думку, цей вид договору у всіх випадках полягає в момент здачі вантажу відправником і є, отже, реальним. На реальний характер такого договору вказують норми Брюссельської конвенції про коносамент 1924 р. [4].

Однак іноді вантажовідправнику буває необхідно заручитися певною гарантією перевезення вантажу заздалегідь або він планує здійснювати регулярні відправки вантажу протягом тривалих періодів. У цьому разі попередня домовленість про бронювання місця на судні оформляється букінг-нотом, у якому зазначаються назва і кількість вантажу, терміни відправки, інші умови. Такий договір слід віднести до консенсуальних.

Правова природа коносамента визначається трьома функціями цього документа: 1) він виступає як товаророзподільчий документ щодо зазначеного в ньому вантажу; 2) є розпискою перевізника в отриманні вантажу від відправника; 3) $€$ доказом наявності та змісту договору морського перевезення вантажу.

Спочатку коносамент виступав лише в ролі розписки перевізника в отриманні вантажу. 3 розвитком лінійного судноплавства, яке обмежило сферу застосування чартеру, зросла роль коносамента як доказ наявності та змісту договору морського перевезення вантажу. Як було відзначено вище, коносамент $є$ не договором перевезення, а лише одним зі свідчень його укладення й умов.

Регламентація чартеру здійснюється за допомогою диспозитивних норм національного законодавства. КТМ Украіни, як і більшість законодавств морських держав, відносить регламентацію відносин із чартером на розсуд сторін.

Складна юридична природа договору морського перевезення вантажу полягає саме в тому, що договір фрахтування на рейс (чартер) віднесений законодавцем до договору морського перевезення вантажу як різновиду цього договору.

Чартер зазвичай розрахований на перевезення великих партій масових вантажів, тому іiі умовою виступає 
надання всього судна, його частини або певних суднових приміщень. Як зазначає I.M. Макаров: «Ця риса чартеру, по-перше, вимагає узгодження широкого кола умов, що належать не тільки до самого перевезення, але й до характеристики судна, i, по-друге, ускладнює оцінку правової природи чартеру, оскільки у відносинах сторін виникають елементи оренди» [10, с. 78-80].

У запропонованій статmі визначається, щз розвиток бізнесу, розширення міжнародних відносин вимагають віо учасників мобільносmi й оперативності пересування, що не завжди забезпечується регулярним повітряним сполученням. Все ие зумовило розвиток сегменту чартерних перевезень.

Договором фрахтування судна називають як договір перевезення вантажів, пасажирів, багажу, якщо він укладений з умовою надання для перевезення всього судна або окремих суднових приміщень, так $i$ договір оренди судна з екіпажем або без нього. I в тому, $i$ в іншому випадку сторони можуть називатися однаково «фрахтувальник (судновласник)» $i$ «ррахтувальник», предмет договору - переміщення певних обумовлених об'єктів (вантажів, пасажирів, багажу) може бути один $і$ той самий.

Акиентується увага на тому, що договір фрахтування (чартер) $є$ двостороннім $і$ оплатним, зміст якого полягає у праві фрахтувальника зарезервувати все обумовлене договором судно, інший транспортний засіб (частину його місткості) для перевезення за плату протягом одного або декількох рейсів, передбачених ияим договором вантажів, пасажирів $i$ багажу, а фрахтувальника - отримати за наданий транспортний засіб (частину його місткості) встановлену угодою сторін плату (іменовану в морському праві фрахтом).

Пропонуеться виділяти такі ознаки лінійного судноплавства: 1) регулярність повідомлення і наяв- ність розкладу судів; 2) перевезення дорогих генеральних вантажів; 3) завантаження судна вантажами багатьох вантажовідправників; 4) оплата перевезення за лінійними тарифами; 5) здійснення вантажно-розвантажувальних операцій перевізником; 6) публічний характер послуг перевізника.

Водночас українське право застосовує поняття «договір фрахтування» виключно до перевезення вантажів, пасажирів, багажу. Всі інші форми експлуатації суден є договором оренди судна як транспортного засобу.

Чартер зазвичай розрахований на перевезення великих партій масових вантажів, тому ї умовою виступає надання всього судна, його частини або певних суднових примішень.

Звертається увага на те, щз, хоча відносини фрахтування (чартеру) в морському праві детально регламентовані на законодавчому рівні, чинне законодавство України в изій сфері не є досконалим.

Ключові слова: послуги, цивільно-правовий договір, перевезення, чартер, коносамент.

Kolodin A. Concerning the features of the charter agreement (chartering) under the civil law of Ukraine

The proposed article defines that business development, expansion of international relations require mobility and speed of travel participants, which is not always provided by regular air services. All this led to the development of the charter segment.

The contract of chartering of a vessel is referred to as the contract of carriage of goods, passengers, luggage, if it is concluded with the condition of providing for the carriage of the whole vessel or individual ship premises, and the lease agreement of the vessel with or without crew.

Attention is drawn to the fact that the charter agreement (charter) is bilateral and paid, the content of which lies in the right of the charterer to reserve all 
the contract stipulated by the vessel, another vehicle (part of its capacity) for transportation for payment for one or more flights stipulated by this contract and cargo luggage, and the charterer - to receive for the provided vehicle (part of its capacity) a fee fixed by agreement of the parties (named in maritime law by freight).

It is proposed to distinguish the following features of linear navigation: 1) the regularity of the notification and the availability of the timetable; 2) transportation of expensive general cargo; 3) loading the ship with the loads of many consignors; 4) payment of transportation at linear tariffs; 5) carrying out loading and unloading operations by the carrier; 6) the public nature of the carrier's services.

In both cases, the parties may be called the same - "charterer (shipowner)" and "charterer", the subject of the contractthe movement of certain stipulated objects (cargo, passengers, luggage) may be the same.

At the same time, Ukrainian law applies the concept of "chartering contract" exclusively to the carriage of goods, passengers, luggage. All other forms of exploitation of vessels are a lease agreement for a vessel as a vehicle.

The charter is usually designed for the carriage of large lots of bulk cargo, so its condition is to provide the whole ship, part or certain ship's premises.

It can be noted that although the chartering relationship in the maritime law is regulated in detail at the legislative level, at the same time the current legislation of Ukraine in this area is not perfect.

Key words: services, civil contract, transportation, charter, bill of lading.

\section{Література}

1. Конституція України : Закон Украіни від 28 червня 1996 р. Відомості Верховної Ради. 1996. № 30. Cm. 141.

2. Цивільний Кодекс України : Закон України від 16 січня 2003 р. № 40-44. URL: https: / / zakon.rada.gov.ua/laws / show/435-15 (дата звернення: 03.01.2020).
3. Кодекс торговельного мореплавства України : Закон України від 23 травня 1995 р. № 176/95-ВР. Відомості Верховної Ради України. 1995. № 47-52. Ст. 349. URL: https://zakon.rada.gov.ua/laws / show / $176 / 95-\%$ D0\% B2\% D1\% 80\#top.

4. Міжнародна конвенція про уніфікацію деяких правил про коносамент від 25 серпня 1924 p. URL: http:// zakon4.rada.gov.ua/laws/show/995_221.

5. Конвенція Організації Об’єวнаних Націй про морське перевезення вантажів від 31 березня 1978 p. URL: http:// zakon4.rada.gov.ua/laws/ show/995_391/ card6\#Public.

6. Конвенція організацї об’єднаних Націй про договори повного або часткового морського міннародного перевезення вантажів від 11 грудня 2008 p. URL: http:// www.un.org / ru/documents / decl_conv/ conventions / carriage_of_goods.shtml.

7. Про затвердження Інструкиії про порядок реєстращіі ліній закордонного плавання. Наказ Міністерства Інфраструктури України від 14 жовтня 2013 р. № 790, Зареєстрований в Міністерстві юстицї України 01 листопада 2013 р. за № 1859/24391. URL: https://zakon.rada. gov.ua/laws/show/z1859-13.

8. Азімов Ч.Н., Сібільов М.М., Борисова B.I. та ін. Цивільне право України. Ч. 1 : підручник. 2000

9. Коваль П.Ф., Алєшугіна Н.О., Андрєєва Г.П. В'їзний туризм : навчальний посібник. Ніжин : Видавництво Лук'яненко В.В., 2010. 304 c.

10. Макаров И.М. Понятие договора морской перевозки. Науковий вісник міжнародного гуманітарного університету. 2011. № 1. C. 78-80.

11. Муранов А.И., Давиденко Д.Л. Унификация и согласование права международной торговли: развитие, проблемь и тенденции. Журнал зарубежного законодательства и сравнительного правоведения. 2008. № 3. С. 81-86.

12. Столярський О.В. Правове регулювання міннародних перевезень : навчальний посібник. Київ : Знання, 2012. 318 c.

13. Цивільне право України. Договірні та недоговірні зобов'язання : підручник / C.С. Бичкова, I.А. Бірюков, В.І. Бобрик та ін. ; за заг. ред. С.С. Бичкової. Київ : Aлерта, 2014. 496 c.

14. Цивільне право : підручник : у $2 \mathrm{~m}$. / B.I. Борисова, Л.М. Баранова, Т.І. Бєгова та ін. ; за ред. В.І. Борисової, I.В. Фатєєвої, В.Л. Яроцького. Харків : Право, 2011. Т. 2. $816 \mathrm{c}$. 